\title{
The importance of thinking about Guillain-Barré syndrome during the COVID-19 pandemic: a case with pure dysautonomic presentation
}

\author{
Erica Biassoni ${ }^{1,2,3}$ - Andrea Assini ${ }^{3} \cdot$ Ilaria Gandoglia $^{3} \cdot$ Luana Benedetti $^{2} \cdot$ Silvia Boni $^{4} \cdot$ Emanuele Pontali $^{4}$. \\ Marcello Feasi ${ }^{4} \cdot$ Federica Gandolfo $^{5} \cdot$ Massimo Del Sette ${ }^{2,3}$
}

Received: 13 January 2021 / Revised: 8 June 2021 / Accepted: 29 June 2021 / Published online: 2 August 2021

(c) The Author(s) 2021

\begin{abstract}
Guillain-Barré syndrome (GBS) is a peripheral nervous system disease caused by an immune-mediated inflammatory mechanism, usually triggered by a previous infectious process or vaccine; its typical presentation is a rapid and progressive bilateral limb hyposthenia, associated with sensory deficits and reduction or absence of osteotendinous reflexes. However, also autonomic nervous system can be involved with heart rate fluctuations, blood pressure instability, pupillary dysfunction, and urinary retention. Since the beginning of COVID-19 pandemic, GBS has been reported among neurological complications of SARS-CoV-2 infection, although etiopathological mechanisms still have to be clearly defined. We report the case of a 79-year-old man with multiple comorbidities, including diabetes, who was affected by SARS-CoV-2 interstitial pneumonia and developed dysautonomic symptoms after 10 days of hospitalization. A neurological evaluation was performed, and GBS was considered as a possible cause of the clinical manifestations. This hypothesis was confirmed by electrophysiological study and further supported, ex-juvantibus, by the satisfactory response to immunoglobulin treatment. In our opinion, this case of pure dysautonomic presentation of GBS in a SARS-CoV-2 positive patient is relevant because it suggests to consider GBS upon SARS-CoV-2 infection even if the symptoms have uncommon characteristics (e.g., pure vegetative manifestations) and if there are confounding factors which could lead to a misdiagnosis (e.g., old age, SARS-CoV-2 infection consequences and diabetes).
\end{abstract}

Keywords Guillain-Barré syndrome · SARS-CoV-2 $\cdot$ COVID-19 neurological complications · Dysautonomia

Guillain-Barré syndrome (GBS) is an immune-mediated inflammatory disease of the peripheral nervous system, usually preceded (4-6 weeks before) by viral infections

Erica Biassoni

erica.biassoni@gmail.com

1 Department of Neuroscience, Rehabilitation, Ophthalmology, Genetics and Maternal and Child Health (DiNOGMI), University of Genoa, Largo Paolo Daneo 3, 16132 Genova, Italy

2 IRCCS Ospedale Policlinico San Martino, Largo Rosanna Benzi 10, 16132 Genova, Italy

3 Neurologic Unit, Galliera Hospital, Via Mura delle Cappuccine 14, 16128 Genova, Italy

4 Department of Infectious Diseases, Galliera Hospital, Via Mura delle Cappuccine 14, 16128 Genova, Italy

5 Geriatric Unit, Galliera Hospital, Via Mura delle Cappuccine 14, 16128 Genova, Italy or vaccinations (Leonhard et al. 2019). The most typical presentation is rapid and progressive bilateral symmetrical limb weakness associated with sensory deficits and reduced or absent reflexes, yet several clinical variants have been described. Weakness usually starts from lower limbs and progresses to upper limbs, cranial muscles and, in the $20 \%$ of cases, respiratory muscles. Involvement of the autonomic nervous system can also occur, causing heart rate fluctuations, blood pressure instability, pupillary dysfunction, and urinary retention (Leonhard et al. 2019). A variant of GBS, presenting as acute autonomic neuropathy, has also been reported (Koike et al. 2013).

Recently, GBS has been reported as a possible neurological complication of SARS-CoV-2 infection (Assini et al. 2020; Sriwastava et al. 2021), even if its mechanisms remain to be clarified (Ahmad and Rathore, 2020; Azizi and Azizi, 2020).

We report the case of a 79-year-old man, with diabetes and hypertension, who was admitted to our hospital 
because of thoracic pain, dyspnea, and fever. After chest computed tomography (CT) scan and nasopharyngeal swab, SARS-CoV-2 interstitial pneumonia was diagnosed. The patient was treated with oxygen, intravenous antiviral (remdesivir $200 \mathrm{mg}$ on the first day, followed for the next 4 days by $100 \mathrm{mg}$ ), antibiotics (azithromycin and ceftriaxone), steroids, low molecular weight heparin, and insulin. After 10 days of hospitalization, respiratory symptoms progressively improved without require of intubation or vasopressor therapy (Metlay et al. 2019). Dysautonomic symptoms instead appeared, with acute urinary retention and several episodes of dizziness and reduction of level consciousness during orthostatism. Transthoracic echocardiography excluded valvular heart disease or other cardiac causes of syncope.

During lipothymic episodes, vital signs and glycemia were normal, although values of systolic blood pressure (BP) under $80 \mathrm{mmHg}$ were recorded in orthostatism. Tilt test resulted positive: $\mathrm{BP}$ in supine position was $110 / 70 \mathrm{mmHg}$; in sitting position, after $1 \mathrm{~min}$, BP decreased to $80 / 60 \mathrm{mmHg}$, and after $3 \mathrm{~min}$, systolic BP lowered to $70 \mathrm{mmHg}$ and patient began to blame dizziness. Therapy with midodrine, fludrocortisone, and elastic stockings was started.

Neurological examination was normal, except for absence of osteotendinous reflexes and mild confusional state.

Cerebral CT scan was normal, while neurophysiological examination, performed 6-7 days after symptoms onset, showed a reduction of conduction speed, temporal dispersion of potentials, late response, and $\mathrm{F}$ wave alterations, meaning both myelin and axonal damage (Table 1). We used the elec- trophysiological normative values of our neurophysiopathology laboratory, based on Kimura's international references (Kimura, 2013). Cerebro-spinal fluid (CSF) analysis showed mild increase in proteins $(45.30 \mathrm{mg} / \mathrm{dl})$. Cell count was normal, and oligoclonal bands both in CSF and serum were negative. Search for SARS-CoV-2 virus and antibodies in CSF was negative, while serology for SARS-CoV-2 showed the presence of IgG but not IgM. Search for anti-ganglioside antibodies was negative (both IgG and IgM).

Given the hypothesis of GBS, 9 days after dysautonomic symptom onset, therapy with intravenous immunoglobulins was started, with partial improvement of dysautonomic symptoms. The Modified Erasmus GBS Outcome Score (mEGOS) was 2 (Waalgard et al. 2011). After about 28 days of hospitalization, SARS-CoV-2 swab turned negative and the patient was transferred to a rehabilitation center.

During rehabilitation, orthostatic hypotension improved and about 4 weeks after hospital discharge the patient was able to walk without support. This favorable outcome was in line with the patient's low mEGOS value at the onset of neurological symptoms.

In our opinion, this case gives the opportunity to discuss several crucial points regarding the possible neurological complications of SARS-CoV-2 infections. From a clinical point of view, there were some confounding factors: indeed, autonomic impairment could have been attributed to other coexisting factors, such as diabetic neuropathy, patient's age, and muscular weakness due to SARS-CoV-2 infection. SARS-CoV-2 infection

Table 1 Electrophysiological data

\begin{tabular}{|c|c|c|c|c|c|}
\hline Examined nerves & $\begin{array}{l}\text { Motor/sensory distal } \\
\text { latency }\end{array}$ & Distal amplitude & Conduction velocity & F wave & Damage pattern \\
\hline $\begin{array}{l}\text { Left deep peroneal } \\
\text { nerve }\end{array}$ & $\begin{array}{l}7.1 \mathrm{~m} \\
\text { (normal values less } \\
\text { than } 4.5 \mathrm{~ms} \text { ) }\end{array}$ & $\begin{array}{l}0.9 \mathrm{mV} \\
\text { (normal values greater } \\
\text { than } 2.5 \mathrm{mV} \text { ) }\end{array}$ & $\begin{array}{l}34.6 \mathrm{~m} / \mathrm{s} \\
\text { (normal values greater } \\
\text { than } 40 \mathrm{~m} / \mathrm{s} \text { ) }\end{array}$ & I & $\begin{array}{l}\text { Mixed (distal and proxi- } \\
\text { mal demyelination and } \\
\text { axonal motor damage) }\end{array}$ \\
\hline $\begin{array}{l}\text { Right posterior tibial } \\
\text { nerve }\end{array}$ & $\begin{array}{l}4.2 \mathrm{~ms} \\
\text { (normal values less } \\
\text { than } 5.5 \mathrm{~ms} \text { ) }\end{array}$ & $\begin{array}{l}4.2 \mathrm{mV} \\
\text { (normal values greater } \\
\text { than } 5 \mathrm{mV} \text { ) }\end{array}$ & $\begin{array}{l}33.6 \mathrm{~m} / \mathrm{s} \\
\text { (normal values greater } \\
\text { than } 40 \mathrm{~m} / \mathrm{s} \text { ) }\end{array}$ & $\begin{array}{l}58 \mathrm{~ms} \text {; poorly } \\
\text { persistent } \\
\text { (normal value: } \\
\text { minimal } \\
\text { latency of less } \\
\text { than } 56 \mathrm{~ms} \text { ) }\end{array}$ & $\begin{array}{l}\text { Proximal demyelination } \\
\text { and altered } \mathrm{F} \text { wave }\end{array}$ \\
\hline Right sural nerve & $2.5 \mathrm{~ms}$ & $\begin{array}{l}1.5 \mathrm{mV} \\
\text { (normal values greater } \\
\text { than } 5 \mu \mathrm{V} \text { ) }\end{array}$ & $\begin{array}{l}42.7 \mathrm{~m} / \mathrm{s} \\
\text { (normal values greater } \\
\text { than } 40 \mathrm{~m} / \mathrm{s} \text { ) }\end{array}$ & / & Axonal damage \\
\hline $\begin{array}{l}\text { Left superficial pero- } \\
\text { neal nerve }\end{array}$ & Not evoked & $\begin{array}{l}\text { Not evoked } \\
\text { (normal values greater } \\
\text { than } 5 \mu \mathrm{V} \text { ) }\end{array}$ & $\begin{array}{l}\text { Not evoked } \\
\text { (normal values greater } \\
\text { than } 40 \mathrm{~m} / \mathrm{s} \text { ) }\end{array}$ & I & Axonal damage \\
\hline Right median nerve & $\begin{array}{l}8.3 \mathrm{~ms} \\
\text { (normal values less } \\
\text { than } 4.2 \mathrm{~ms} \text { ) }\end{array}$ & $\begin{array}{l}1.1 \mathrm{mV} \\
\text { (normal values greater } \\
\text { than } 5 \mathrm{mV} \text { ) }\end{array}$ & $\begin{array}{l}\text { Conduction block } \\
\text { between elbow and } \\
\text { wrist } \\
\text { (normal values } \\
\text { between elbow and } \\
\text { wrist greater than } \\
50 \mathrm{~m} / \mathrm{s} \text { ) }\end{array}$ & $\begin{array}{l}\text { Not evoked } \\
\text { (normal value: } \\
\text { minimal } \\
\text { latency of less } \\
\text { than } 32 \mathrm{~ms} \text { ) }\end{array}$ & $\begin{array}{l}\text { Mixed (proximal and } \\
\text { distal demyelination } \\
\text { with conduction block } \\
\text { and axonal motor } \\
\text { damage) }\end{array}$ \\
\hline
\end{tabular}


itself has also been temporally related to dysautonomic symptoms (Shouman et al. 2021). However, results of neurophysiological study, CSF findings, and response to intravenous immunoglobulin treatment support the diagnosis of GBS, which is included among the possible neurological manifestations after SARS-CoV-2 infection (Ahmad and Rathore, 2020; Sriwastava et al. 2021).

In our case, electrophysiological pattern confirmed the diagnosis of GBS: in fact, while in diabetic neuropathy, the damage is typically axonal and sensory (Feldman et al. 2019); in our patient, the electrophysiological findings, according to Hadden's criteria (Hadden et al. 1998), allowed to identify an acute inflammatory demyelinating neuropathy (AIDP), probably superimposed over a diabetic neuropathy (Table 1). Hyperproteinorrachia was not severe, probably due to the spinal tap performed quite close to symptoms onset (Leonhard et al. 2019).

Interestingly, similar short interval between infection and GBS onset has been previously reported in other patients with SARS-CoV-2-related GBS (Toscano et al. 2020). In these cases, classifiable more as parainfectious than postinfectious GBS, the pathogenetic mechanism could be ascribed to an aberrant immune response rather than the typical molecular mimicry-based mechanism.

Limits of our report are that we have not carried out specific electrophysiological tests for dysautonomia; moreover, in our case, serology for SARS-CoV-2 IgM was negative. The presence of IgG alone could be due to seroconversion already occurred from IgM to IgG at the time of the sample collection. Anyway, so far, three different types of seroconversion have been described (Long et al. 2020), one of them consisting in seroconversion to IgG preceding the IgM one.

In this case, dysautonomic symptoms represented the main feature of GBS. Although it does not fulfill all GBS clinical criteria (Fokke et al. 2014), a variant of GBS presenting as acute autonomic neuropathy has already been published (Koike et al. 2013). Moreover, recently an autonomic dysfunction preceding acute motor axonal neuropathy (AMAN) associated with COVID-19 has been reported (Ghosh et al. 2020); as opposed to this case, in our patient, autonomic dysfunction was the only clinical presentation of peripheral neuropathy, whose autoimmune mechanism was confirmed by CSF results and response to immunomodulating therapy.

In conclusion, we believe that our case of pure dysautonomic presentation of GBS in a patient with SARS-CoV-2 infection is important because it might alert clinicians to search for GBS after SARS-CoV-2 infection, even in cases of isolated dysautonomic symptoms, especially when there are confounding factors such as old age and diabetes.

Author contribution All the authors contributed to the study conception and design. Material preparation, data collection, and analysis were performed by Erica Biassoni, Andrea Assini, Ilaria Gandoglia, and Massimo Del Sette. Silvia Boni, Emanuele Pontali, Marcello Feasi, and Federica Gandolfo worked on material preparation and data collection. Luana Benedetti worked on data analysis. The first draft of the manuscript was written by Erica Biassoni, and all authors commented on previous versions of the manuscript. All authors read and approved the final manuscript.

Funding Open access funding provided by Università degli Studi di Genova within the CRUI-CARE Agreement.

Open Access This article is licensed under a Creative Commons Attribution 4.0 International License, which permits use, sharing, adaptation, distribution and reproduction in any medium or format, as long as you give appropriate credit to the original author(s) and the source, provide a link to the Creative Commons licence, and indicate if changes were made. The images or other third party material in this article are included in the article's Creative Commons licence, unless indicated otherwise in a credit line to the material. If material is not included in the article's Creative Commons licence and your intended use is not permitted by statutory regulation or exceeds the permitted use, you will need to obtain permission directly from the copyright holder. To view a copy of this licence, visit http://creativecommons.org/licenses/by/4.0/.

\section{References}

Ahmad I, Rathore FA (2020) Neurological manifestations and complications of COVID-19: a literature review. J Clin Neurosci 77:8-12. https://doi.org/10.1016/j.jocn.2020.05.017

Assini A, Benedetti L, Di Maio S, Schirinzi E, Del Sette M (2020) New clinical manifestation of COVID-19 related Guillain-Barrè syndrome highly responsive to intravenous immunoglobulins: two Italian cases. Neurol Sci 41:1657-1658. https://doi.org/10.1007/ s10072-020-04484-5

Azizi SA, Azizi SA (2020) Neurological injuries in COVID-19 patients: direct viral invasion or a bystander injury after infection of epithelial/endothelial cells. Journal of NeuroVirology 26(5):631-664. https://doi.org/10.1007/s13365-020-00903-7

Feldman EL, Callaghan BC, Pop-Busui R, Zochodne DW, Wright DE, Bennett DL, Bril V, Russell JW, Viswanathan V (2019) Diabetic neuropathy. Nat Rev Dis Primers 5(41):1-18. https://doi.org/10. 1038/s41572-019-0092-1

Fokke C, Van Den Berg B, Drenthen J, Walgaard C, Van Doorn PA, Jacobs BC (2014) Diagnosis of Guillain-Barré syndrome and validation of Brighton criteria. Brain 137(1):33-43. https://doi.org/ 10.1093/brain/awt285

Ghosh R, Roy D, Sengupta S, Benito-León J (2020) Autonomic dysfunction heralding acute motor axonal neuropathy in COVID-19. Journal of NeuroVirology 26:964-966. https://doi.org/10.1007/ s13365-020-00908-2

Hadden RDM, Cornblath DR, Hughes RAC, Zielasek J, Hartung HP, Toyka KV, Swan AV (1998) Electrophysiological classification of Guillain-Barre syndrome: clinical associations and outcome. Ann Neurol 44:780-788. https://doi.org/10.1002/ana.410440512

Kimura J (2013) Electrodiagnosis in diseases of nerve and muscle: principles and practice. 4th Edition. Oxford University Press, N.Y. https://doi.org/10.1093/med/9780199738687.001.0001

Koike H, Watanabe H, Sobue G (2013) The spectrum of immune-mediated autonomic neuropathies: insights from the clinicopathological features. J Neurol Neurosurg Psychiatry 84(1):98-106. https://doi.org/ 10.1136/jnnp-2012-302833

Leonhard SE, Mandarakas MR, Gondim FAA, Bateman K, Ferreira MLB, Cornblath DR, van Doorn PA, Dourado ME, Hughes RAC, 
Islam B, Kusunoki S, Pardo CA, Reisin R, Sejvar JJ, Shahrizaila N, Soares C, Umapathi T, Wang Y, Yiu EM, Willison HJ, Jacobs BC (2019) Diagnosis and management of Guillain-Barré syndrome in ten steps. Nat Rev Neurol 15:671-683. https://doi.org/10.1038/ s41582-019-0250-9

Long QX, Liu BZ, Deng HJ et al (2020) Antibody responses to SARSCoV-2 in patients with COVID-19. Nat Med 26:845-848. https:// doi.org/10.1038/s41591-020-0897-1

Metlay JP, Waterer GW, Long AC, Anzueto A, Brozek J, Crothers K, Cooley LA, Dean NC, Fine MJ, Flanders SA, Griffin MR, Metersky ML, Musher DM, Restrepo MI, Whitney CG (2019) Diagnosis and treatment of adults with community-acquired pneumonia. An Official Clinical Practice Guideline of the American Thoracic Society and Infectious Diseases Society of America. Am J Respir Crit Care Med 200(7):e45-e67. https://doi.org/10.1164/ rccm.201908-1581ST

Shouman K, Vanichkachorn G, Cheshire WP et al (2021) Autonomic dysfunction following COVID-19 infection: an early experience. Clin Auton Res https://doi.org/10.1007/s10286-021-00803-8
Sriwastava S, Kataria A, Tandon M, Patel J, Patel R, Jowkar A, Daimee M, Bernitsas E, Jaiswal P, Lisak RP (2021) Guillain Barré Syndrome and its variants as a manifestation of COVID-19: a systematic review of case reports and case series. J Neurol Sci 420:117263. https://doi. org/10.1016/j.jns.2020.117263

Toscano G, Palmerini P, Ravaglia S, Ruiz L, Invernizzi P, Cuzzoni MG, Franciotta D et al (2020) Guillain-Barré syndrome associated with SARS-CoV-2. N Engl J Med 382(26):2574-2576. https://doi.org/ 10.1056/NEJMc2009191

Walgaard C, Lingsma HF, Ruts L, van Doorn PA, Steyerberg EW, Jacobs BC (2011) Early recognition of poor prognosis in Guillain-Barré syndrome. Neurology 7611968 975. https://doi.org/10.1212/WNL. 0b013e3182104407

Publisher's Note Springer Nature remains neutral with regard to jurisdictional claims in published maps and institutional affiliations. 